\title{
Seasonal Variation of Anammox and Denitrification in Sediments of Two Eutrophic Urban Lakes
}

\author{
Jianwei Zhao*, Duanwei Zhu, Junnan Fan, Yumei Hua, Wenbing Zhou \\ Laboratory of Eco-Environmental Engineering Research of Huazhong Agricultural University, \\ Key Laboratory of Arable Land Conservation (Middle and Lower Reaches of Yangtze River), \\ Ministry of Agriculture, Wuhan 430070, China
}

Received: April 15, 2015

Accepted: August 27, 2015

\begin{abstract}
For this study a ${ }^{15} \mathrm{~N}$ isotope culture was prepared in sediments collected from two eutrophic lakes to determine the potential for the anammox process and denitrification of the sediments. Test result showed that the average reaction rate of the anammox process for the entire year is $137 \pm 77 \mu \mathrm{mol} \mathrm{N} \cdot \mathrm{m}^{-2} \cdot \mathrm{h}^{-1}$, contributing $10.4 \%$ to nitrogen gas evolution from the sediments. The anammox process in the lake has an obvious seasonal affect in the following order: summer $\left(237 \pm 83 \mu \mathrm{mol} \mathrm{N} \cdot \mathrm{m}^{-2} \cdot \mathrm{h}^{-1}\right)>$ autumn $\left(133 \pm 30 \mu \mathrm{mol} \mathrm{N} \cdot \mathrm{m}^{-2} \cdot \mathrm{h}^{-1}\right)>$ spring $\left(90 \pm 24 \mu \mathrm{mol} \mathrm{N} \cdot \mathrm{m}^{-2} \cdot \mathrm{h}^{-1}\right)>$ winter $\left(87 \pm 26 \mu \mathrm{mol} \mathrm{N} \cdot \mathrm{m}^{-2} \cdot \mathrm{h}^{-1}\right)$. A positive correlation $(\mathrm{P}<0.01)$ exists between the rates of the anammox process and denitrification.
\end{abstract}

Keywords: anammox, denitrification, lake sediment, seasonal variation

\section{Introduction}

Enrichment of nitrogen nutrients is one of the major reasons for eutrophication of lakes. Denitrification and anammox are the two main microbial processes involved in the removal of nitrogen through the production of nitrogen gas $\left(\mathrm{N}_{2}\right)$. Denitrification is a well-studied process in which nitrate and nitrite are converted to $\mathrm{N}_{2}$. The primary factors influencing the rate of denitrification included dissolved oxygen, temperature, and nitrate in sediments $[1,2]$. The anammox process is a reaction exhibited by the anammox bacteria that oxidizes $\mathrm{NH}_{4}^{+}$into $\mathrm{N}_{2}$, with $\mathrm{NH}_{4}^{+}$as the electron donor and $\mathrm{NO}_{2}^{-}$as the electron acceptor under anaerobic conditions. So this reaction is favorable for removing dissolved inorganic nitrogen which is a key contributor to rapid growth of algae. In 2002 the anammox process was found to generate 24 and $67 \%$ of the total $\mathrm{N}_{2}$ production at two typical continental

*e-mail: jwzhao2@163.com shelf sites [3]. In the next year, other study showed the reaction accounted for $19-35 \%$ of the total $\mathrm{N}_{2}$ formation in the anoxic water column of Golfo Dulce, Costa Rica [4], thus demonstrating that this reaction has a significant influence on the marine nitrogen cycle. Trimmer et al. proposed that the anammox process was controlled by the concentrations of nitrite and nitrate in estuarine sediments [5]. The study of Rich et al. in the Chesapeake Bay sediments indicated that the percentage of $\mathrm{N}_{2}$ production was related to salinity and nitrates in the overlying water [6]. The anammox process has also been detected in freshwater ecosystems [7, 8], and anammox bacteria exist in both shallow lake $(<1 \mathrm{~m})$ [9] and river sediments [10]. Yoshinaga et al. found that the distribution of the anammox bacteria is extensive and diverse in the sediments of eutrophic freshwater lakes [11]. At present, research on nitrogen productivity resulting from the anammox process in freshwater ecosystems is rare. An extensive understanding of the effects and state of this process in the nitrogen cycle of lakes is also lacking. 
Table 1. Environmental parameters of sampling sites in Donghu and Nanhu lakes. Values are means (SD); $\mathrm{n}=5$.

\begin{tabular}{|c|c|c|c|c|c|c|c|c|c|c|}
\hline \multirow{3}{*}{ Lake } & \multirow{3}{*}{$\begin{array}{l}\text { Sampling } \\
\text { date }\end{array}$} & \multicolumn{5}{|c|}{ Overlying water } & \multicolumn{3}{|c|}{ Pore water } & \multirow{3}{*}{$\begin{array}{c}\text { Sediment } \\
\mathrm{OM} \\
(\mathrm{g} / \mathrm{kg})\end{array}$} \\
\hline & & \multirow{2}{*}{$\begin{array}{c}\mathrm{T} \\
\left({ }^{\circ} \mathrm{C}\right)\end{array}$} & $\mathrm{NH}_{4}^{+}-\mathrm{N}$ & $\mathrm{NO}_{2}^{-}-\mathrm{N}$ & $\mathrm{NO}_{3}^{-}-\mathrm{N}$ & $\mathrm{TP}$ & $\mathrm{NH}_{4}^{+}-\mathrm{N}$ & $\mathrm{NO}_{2}^{-}-\mathrm{N}$ & $\mathrm{NO}_{3}^{-}-\mathrm{N}$ & \\
\hline & & & \multicolumn{4}{|c|}{$(\mathrm{mg} / \mathrm{L})$} & \multicolumn{3}{|c|}{$(\mathrm{mg} / \mathrm{L})$} & \\
\hline \multirow{4}{*}{ Donghu } & March 23 & $11.3 \pm 0.1$ & $1.0 \pm 0.4$ & $0.01 \pm 0.00$ & $0.23 \pm 0.03$ & $0.16 \pm 0.04$ & $6.4 \pm 5.2$ & $0.04 \pm 0.05$ & $0.58 \pm 0.36$ & $57 \pm 14$ \\
\hline & June 27 & $26.7 \pm 0.2$ & $0.5 \pm 0.3$ & $0.05 \pm 0.02$ & $0.33 \pm 0.09$ & $0.11 \pm 0.08$ & $3.5 \pm 2.1$ & $0.10 \pm 0.10$ & $0.51 \pm 0.25$ & $48 \pm 12$ \\
\hline & Sept. 14 & $26.6 \pm 1.0$ & $1.4 \pm 0.4$ & $0.01 \pm 0.02$ & $0.33 \pm 0.07$ & $0.25 \pm 0.09$ & $4.6 \pm 3.1$ & $0.12 \pm 0.17$ & $1.50 \pm 1.05$ & $38 \pm 15$ \\
\hline & Nov. 10 & $15.9 \pm 0.1$ & $0.5 \pm 0.1$ & $0.01 \pm 0.00$ & $0.35 \pm 0.06$ & $0.11 \pm 0.03$ & $5.4 \pm 3.5$ & $0.02 \pm 0.03$ & $1.42 \pm 1.49$ & $41 \pm 15$ \\
\hline \multirow{4}{*}{ Nanhu } & March 23 & $12.1 \pm 1.2$ & $5.8 \pm 3.9$ & $0.03 \pm 0.02$ & $0.55 \pm 0.28$ & $0.39 \pm 0.18$ & $8.2 \pm 5.2$ & $0.02 \pm 0.03$ & $0.50 \pm 0.33$ & $53 \pm 13$ \\
\hline & June 27 & $27.0 \pm 0.8$ & $3.9 \pm 1.6$ & $0.55 \pm 0.20$ & $1.09 \pm 0.20$ & $0.55 \pm 0.32$ & $4.3 \pm 3.8$ & $0.04 \pm 0.04$ & $0.50 \pm 0.24$ & $43 \pm 13$ \\
\hline & Sept. 14 & $25.5 \pm 3.3$ & $3.9 \pm 1.5$ & $0.08 \pm 0.05$ & $0.64 \pm 0.24$ & $0.50 \pm 0.12$ & $4.9 \pm 3.9$ & $0.05 \pm 0.09$ & $1.09 \pm 0.45$ & $50 \pm 13$ \\
\hline & Nov. 10 & $15.7 \pm 0.4$ & $1.1 \pm 0.6$ & $0.02 \pm 0.02$ & $2.12 \pm 1.80$ & $0.21 \pm 0.09$ & $6.1 \pm 4.1$ & $0.01 \pm 0.02$ & $1.57 \pm 2.03$ & $51 \pm 13$ \\
\hline
\end{tabular}

The main objective of the present research is to determine the seasonal variation of the anammox process in sediments in two eutrophic urban lakes in Wuhan, China.

\section{Experimental Procedures}

\section{Study Area and Sample Collection}

Donghu Lake, with an area of $33.7 \mathrm{~km}^{2}$, and Nanhu Lake, with an area of $7.64 \mathrm{~km}^{2}$ in Wuhan City, Hubei Province of China, were selected as the study objects. These lakes are urban lakes and the sanitary sewage discharge around lakes containing a large amount of ammonium and nitrate led to lake eutrophication (Table 1). The average depths of Donghu and Nanhu are $2.5 \mathrm{~m}$ and $2.3 \mathrm{~m}$, respectively, and the disturbance of surface sediments by wind wave is significant. Donghu and Nanhu have five sampling sites each. The sites in Donghu are situated between north latitude $30^{\circ} 32^{\prime} 58^{\prime \prime}$ to $30^{\circ} 34^{\prime} 42^{\prime \prime}$, and east longitude $114^{\circ} 21^{\prime} 03^{\prime \prime}$ to $114^{\circ} 23^{\prime} 30^{\prime \prime}$, whereas other sites in Nanhu are situated between north latitude $30^{\circ} 28^{\prime} 35^{\prime \prime}$ to $30^{\circ} 29^{\prime} 01^{\prime \prime}$ and east longitude $114^{\circ} 21^{\prime} 45^{\prime \prime}$ to $114^{\circ} 22^{\prime} 15^{\prime \prime}$.

Sample analyses and culture experiments were conducted simultaneously on both lakes for each sampling site on March 23 (spring), June 27 (summer), September 14 (autumn), and November 10 (winter) 2011. A water quality meter (YSI Pro Plus, USA) was used to determine the parameter of the overlying water at $0.5 \mathrm{~m}$ of the sediment surface. Two sediment cores with $50 \mathrm{~mm}$ in diameter were collected by plexiglass sampling tubes in each sampling site, and sediment samples from $20 \mathrm{~cm}$ of the surface were obtained to determine physical and chemical indexes.

\section{Measuring the Potential Rates of the Anammox} Process and Denitrification via ${ }^{15} \mathrm{~N}$ Isotopic Tracing

On each sampling date and from each of the 10 sites at the two lakes, mixed sediment samples $(5 \mathrm{~mL})$ that had been preincubated for $24 \mathrm{~h}$ under anaerobic conditions to remove residual $\mathrm{NO}_{\mathrm{X}}^{-}[12]$ were placed in an anaerobic bottle $(65 \mathrm{~mL})$ that was always placed in a sealed glove bag (Atmosbag, $280 \mathrm{~L}$ ) filled with helium gas to prevent outer air from entering the bottle. Then, $20 \mathrm{~mL}$ filtered overlying water sample with $200 \mu \mathrm{M} \mathrm{Na}{ }^{15} \mathrm{NO}_{3}$ (abundance of ${ }^{15} \mathrm{~N}$ : 99.2\%, Shanghai Engineering Research Center of Stable Isotope) was added to the sample $[13,14]$. Subsequently, the bottle contents were purged with high-purity helium gas for $10 \mathrm{~min}$ to remove remaining air. After purging, a butyl rubber plug was immediately inserted to seal the bottle tightly, and then the bottle was wrapped with a black-out cloth for incubation. The incubation time was $24 \mathrm{~h}$ at a constant temperature the same as that of the overlying water in the sampling site (Table 1). At incubation endpoint, $0.2 \mathrm{~mL}$ saturated $\mathrm{HgCl}_{2}$ solution was added by using a $1 \mathrm{~mL}$ syringe to terminate the reaction and balance the concussion for $2 \mathrm{~h}$. Then the produced ${ }^{29} \mathrm{~N}_{2}$ and ${ }^{30} \mathrm{~N}_{2}$ on the headspace of the anaerobic bottle was extracted by a syringe and measured by a gas chromatograph-isotope ratio mass spectrometer (Gasbench-MAT253, Thermo Fisher Scientific, USA). The nitrogen production rates of the anammox process and denitrification were calculated with the formula presented by Thamdrup and Dalsgaard [3].

In the present study, SPSS 11.0 (SPSS Inc., USA) software was used for data analysis, and Origin 8.0 $\left(\right.$ OriginLab $^{\circledR}$, USA) software was used for charting.

\section{Results and Discussion}

Fig. 1 shows the nitrogen productivity of the anammox process for sediments in two lakes during each season. The anammox process rate in sediments in Donghu Lake is highest in summer (June), reaching $248 \pm 71 \mu \mathrm{mol} \mathrm{N} \cdot \mathrm{m}^{-2} \cdot \mathrm{h}^{-1}$, and lowest in winter (November) at $70 \pm 16 \mu \mathrm{mol} \mathrm{N} \cdot \mathrm{m}^{-2} \cdot \mathrm{h}^{-1}$. The variation in anammox process rates in Nanhu is similar to that in Donghu. The rate is highest in summer $\left(225 \pm 92 \mu \mathrm{mol} \mathrm{N} \cdot \mathrm{m}^{-2} \cdot \mathrm{h}^{-1}\right)$ and lowest in winter $(105 \pm 21$ 


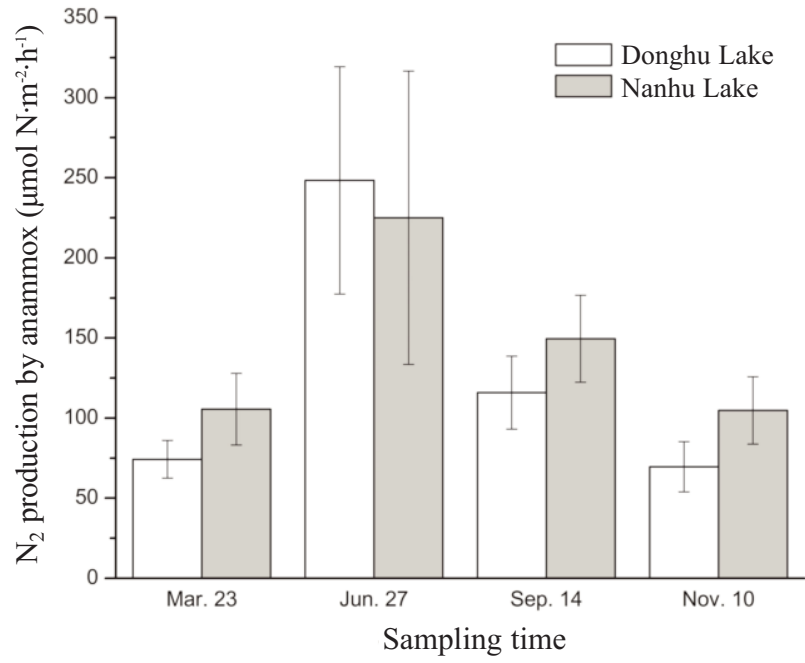

Fig. 1. The $\mathrm{N}_{2}$ production rates by anammox in sediment of two eutrophic lakes. The error bars indicate standard deviations $(\mathrm{n}=5)$.

$\left.\mu \mathrm{mol} \mathrm{N} \cdot \mathrm{m}^{-2} \cdot \mathrm{h}^{-1}\right)$. The average rate of the anammox process in the two lakes, in order of the seasons, is: summer $\left(237 \pm 83 \mu \mathrm{mol} \mathrm{N} \cdot \mathrm{m}^{-2} \cdot \mathrm{h}^{-1}\right)>$ autumn $\left(133 \pm 30 \mu \mathrm{mol} \mathrm{N} \cdot \mathrm{m}^{-2} \cdot \mathrm{h}^{-1}\right)$ $>$ spring $\left(90 \pm 24 \mu \mathrm{mol} \mathrm{N} \cdot \mathrm{m}^{-2} \cdot \mathrm{h}^{-1}\right)>$ winter $(87 \pm 26 \mu \mathrm{mol}$ $\left.\mathrm{N} \cdot \mathrm{m}^{-2} \cdot \mathrm{h}^{-1}\right)$. The rate in summer is nearly twice as high as that in autumn and three times those of spring and winter.

Fig. 2 shows the nitrogen productivity of denitrification in sediments in Donghu and Nanhu in each season. The denitrification rate in sediments in Donghu is highest in summer (June), reaching $1,380 \pm 501 \mu \mathrm{mol} \mathrm{N} \cdot \mathrm{m}^{-2} \cdot \mathrm{h}^{-1}$, and lowest in spring (March), $581 \pm 127 \mu \mathrm{mol} \mathrm{N} \cdot \mathrm{m}^{-2} \cdot \mathrm{h}^{-1}$. The denitrification rate in sediments in Nanhu is highest in summer $\left(1,974 \pm 826 \mu \mathrm{mol} N \cdot \mathrm{m}^{-2} \cdot \mathrm{h}^{-1}\right)$ and lowest in spring $\left(1,105 \pm 576 \mu \mathrm{mol} \mathrm{N} \cdot \mathrm{m}^{-2} \cdot \mathrm{h}^{-1}\right)$. The average denitrification rate in the two lakes, in order of the seasons, is as follows: summer $\left(1,677 \pm 745 \mu \mathrm{mol} \mathrm{N} \cdot \mathrm{m}^{-2} \cdot \mathrm{h}^{-1}\right)>$ autumn $(1,317 \pm 600$ $\left.\mu \mathrm{mol} \mathrm{N} \cdot \mathrm{m}^{-2} \cdot \mathrm{h}^{-1}\right)>\operatorname{winter}\left(856 \pm 457 \mu \mathrm{mol} \mathrm{N} \cdot \mathrm{m}^{-2} \cdot \mathrm{h}^{-1}\right)>$ spring $\left(843 \pm 493 \mu \mathrm{mol} \mathrm{N} \cdot \mathrm{m}^{-2} \cdot \mathrm{h}^{-1}\right)$. The rate in summer is nearly twice those in spring and winter.

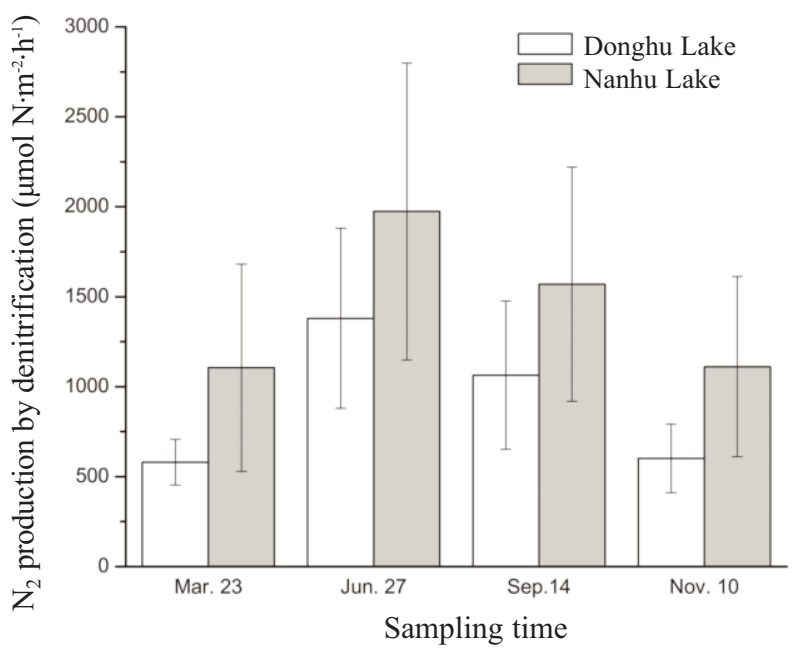

Fig. 2. The $\mathrm{N}_{2}$ production rates by denitrification in sediment of two eutrophic lakes. The error bars indicate standard deviations $(n=5)$.
Several studies have shown that temperature has an obvious influence on the rate of the anammox process. The maximum nitrogen removal rate is observed at $25^{\circ} \mathrm{C}$, and it decreases below $20^{\circ} \mathrm{C}$ and over $33^{\circ} \mathrm{C}$ [15]. In the present research, a positive correlation $(\mathrm{P}<0.01)$ existed between the rate of anammox process and water temperature, and the water temperature is highest in summer, reaching $26.9^{\circ} \mathrm{C}$ (Table 1 ), which is probably the main cause of the highest rate of the anammox process during that season. Whereas pollutant concentrations also have some effect on the anammox, which lead to the different contributions in summer and autumn despite having similar water temperatures both seasons.

The average value of the anammox process rate in the sediments in the two lakes for the entire year is $137 \pm 77$ $\mu \mathrm{mol} \mathrm{N} \cdot \mathrm{m}^{-2} \cdot \mathrm{h}^{-1}$, whereas the average value of denitrification rate is $1,173 \pm 680 \mu \mathrm{mol} \mathrm{N} \cdot \mathrm{m}^{-2} \cdot \mathrm{h}^{-1}$. The overall productivity of nitrogen gas for the entire year is $1,310 \mu \mathrm{mol} \mathrm{N} \cdot \mathrm{m}^{-2} \cdot \mathrm{h}^{-1}$, and the average contribution of the anammox process and denitrification to total $\mathrm{N}_{2}$ production are $10.4 \%$ and $89.6 \%$, respectively. Erler et al. also found that the nitrogen produced by the anammox process in constructed wetlands accounted for $24.0 \%$ of the total $\mathrm{N}_{2}$ production [16]. This finding indicates that the nitrogen produced by the anammox process under eutrophic environments is probably high.

The ratio of nitrogen gas produced by the anammox in marine environments is estimated to be between $30 \%$ and $50 \%$ [4, 17-19]. In some marine ecosystems the anammox process still exhibits obvious advantages, with its contribution exceeding $50 \%[19,20]$. There was much evidence to reveal that the anammox process will be subject to organic matter, nitrite, and nitrate $[21,22]$. This study also showed that a positive correlation $(\mathrm{P}<0.01)$ existed between the rate of anammox process and nitrite concentration both in overlying water and pore water. At present, research findings on nitrogen contributions to freshwater ecosystems remain few. However, several studies have shown that nitrogen contributions are typically lower in freshwater ecosystems than in marine ecosystems. The potential activity of the anammox process accounts for $1 \%$ to $5 \%$ of the total $\mathrm{N}_{2}$ production in paddy fields [23]. Research on Lake Tanganyika in Tanzania shows that approximately $13 \%$ of nitrogen loss is caused by the aforementioned reaction [7]. Only denitrification in the water column was discovered in a temperate permanently stratified lake (Lake Rassnitzer, Germany) in some seasons [8]. In the present research, the nitrogen contribution rate of the anammox process in the two lakes is $10.4 \%$, which is close to that in Lake Tanganyika.

In general, the rate of the anammox process in the sediment is far less than $100 \mu \mathrm{mol} \mathrm{N} \cdot \mathrm{m}^{-2} \cdot \mathrm{h}^{-1}[24,25]$. However, Erler et al. found that the nitrogen produced by the process in constructed wetlands can reach $199 \pm 19 \mu \mathrm{mol} \mathrm{N} \cdot \mathrm{m}^{-2} \cdot \mathrm{h}^{-1}$ [16]. In the present research, the average rate of the anammox process in eutrophic lakes for the entire year is $137 \pm 77$ $\mu \mathrm{mol} \mathrm{N} \cdot \mathrm{m}^{-2} \cdot \mathrm{h}^{-1}$. This result indicates that the high production of the anammox process may be a common phenomenon in nitrogen-rich environments. 


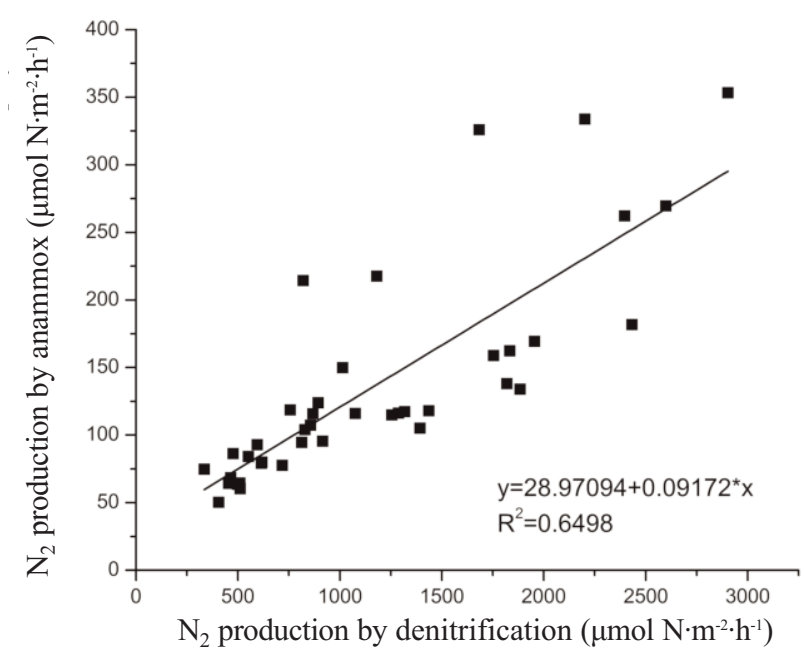

Fig. 3. The relationship of $\mathrm{N}_{2}$ production by denitrification and anammox in eutrophic lake sedimen.

Further analysis shows that a positive correlation exists between the rates of denitrification and the anammox process $(\mathrm{P}<0.01)$. Linear regression relationship also exists between the rates of denitrification and the anammox process (Fig. 3). The reason for this phenomenon may be that the denitrification bacteria provide the anammox bacteria with nitrite, thus enabling the cooperative relationship between the two bacteria. Soil research also proves that anammox, denitrification, and codenitrification can co-occur [26]. Other studies have shown that the anammox process is prominent at deeper depths $(8-10 \mathrm{~cm})$ [13], which means that nitrite production through nitrification at deeper depths could fuel the anammox process. As a mutual substrate in anammox process and denitrification, nitrite leads to a kind of competition between them. However, denitrification can produce a part of nitrite, and perhaps there are cooperative relationships between the two processes. Strengthening the research of source and transformation of nitrite may be beneficial to reveal the internal relationship between these two processes.

\section{Conclusion}

The anammox process has an obvious seasonal effect on sediments in the eutrophic lakes. There was a positive correlation between water temperature and the rate of anammox process $(\mathrm{P}<0.01)$, and temperature changes may be the main reason causing the seasonal difference. And a positive correlation exists between the rates of the anammox process and denitrification $(\mathrm{P}<0.01)$. Therefore, there may be an internal relationship between the two processes. Further stoichiometric research, especially for nitrite, may reveal the relationship.

\section{Acknowledgements}

We acknowledge financial support by the National Natural Science Foundation of China (40901264, 41371452) and the Major Science and Technology Program for Water Pollution Control and Treatment of China (2012ZX07307002, 2014ZX07203-010).

\section{References}

1 OGILVIE B N.D., HARRISON R.M., ROBINSON A., SAGE A. High nitrate, muddy estuaries as nitrogen sinks: The nitrogen budget of the River Colne estuary (United Kingdom). Mar. Ecol. Prog. Ser. 150, (1), 217, 1997.

2 KANA TM S.M., CORNWELL J.C., GROSZKOWSKI K.M. Denitrification in estuarine sediments determined by membrane inlet mass spectrometry. Limnol. Oceanogr. 43, (2), 334, 1998

3 THAMDRUP B., DALSGAARD T. Production of $\mathrm{N}_{2}$ through anaerobic ammonium oxidation coupled to nitrate reduction in marine sediments. Appl. Environ. Microb. 68, (3), 1312, 2002.

4 DALSGAARD T., CANFIELD D.E., PETERSEN J., THAMDRUP B., ACUNA-GONZALEZ J. $\mathrm{N}_{2}$ production by the anammox reaction in the anoxic water column of Golfo Dulce, Costa Rica. Nature 422, (6932), 606, 2003.

5 TRIMMER M., NICHOLLS J.C., MORLEY N., DAVIES C.A., ALDRIDGE J. Biphasic behavior of anammox regulated by nitrite and nitrate in an estuarine sediment. Appl. Environ. Microb. 71, (4), 1923, 2005.

6 RICH J.J., DALE O.R., SONG B., WARD B.B. Anaerobic ammonium oxidation (Anammox) in Chesapeake Bay sediments. Microbial Ecol. 55, (2), 311, 2008.

7 SCHUBERT C.J., DURISCH-KAISER E., WEHRLI B., THAMDRUP B., LAM P., KUYPERS M.M.M. Anaerobic ammonium oxidation in a tropical freshwater system (Lake Tanganyika). Environ. Microbiol. 8, (10), 1857, 2006.

8 HAMERSLEY M.R., WOEBKEN D., BOEHRER B., SCHULTZE M., LAVIK G., KUYPERS M.M.M. Water column anammox and denitrification in a temperate permanently stratified lake (Lake Rassnitzer, Germany). Syst. Appl. Microbiol. 32, (8), 571, 2009.

9 PENTON C.R., DEVOL A.H., TIEDJE J.M. Molecular evidence for the broad distribution of anaerobic ammoniumoxidizing bacteria in freshwater and marine sediments. Appl. Environ. Microb. 72, (10), 6829, 2006.

10 ZHANG Y., RUAN X.H., DEN CAMP H., SMITS T.J.M., JETTEN M.S.M., SCHMID M.C. Diversity and abundance of aerobic and anaerobic ammonium-oxidizing bacteria in freshwater sediments of the Xinyi River (China). Environ. Microbiol. 9, (9), 2375, 2007.

11 YOSHINAGA I., AMANO T., YAMAGISHI T., OKADA K., UEDA S., SAKO Y., SUWA Y. Distribution and diversity of anaerobic ammonium oxidation (Anammox) bacteria in the sediment of a eutrophic freshwater lake, Lake Kitaura, Japan. Microbes and Environments 26, (3), 189, 2011.

12 ZHU G., WANG S., FENG X., FAN G., JETTEN M.S.M., YIN C. Anammox bacterial abundance, biodiversity and activity in a constructed wetland. Environ. Sci. Technol. 45, (23), 9951, 2011.

13 FERNANDES S.O., MICHOTEY V.D., GUASCO S., BONIN P.C., BHARATHI P.A.L. Denitrification prevails over anammox in tropical mangrove sediments (Goa, India). Mar. Environ. Res. 74, 9, 2012.

14 CANION A., KOSTKA J.E., GIHRING T.M., HUETTEL M., VAN BEUSEKOM J.E.E., GAO H., LAVIK G.,KUYPERS M.M.M. Temperature response of denitrification and anammox reveals the adaptation of microbial communities to in situ temperatures in permeable marine sediments that span 50 degrees in latitude. Biogeosciences 11, (2), 309, 2014. 
15 KAWAGOSHI Y., FUJISAKI K., TOMOSHIGE Y., YAMASHIRO K., QIAO Y. Temperature effect on nitrogen removal performance and bacterial community in culture of marine anammox bacteria derived from sea-based waste disposal site. J. Biosci. Bioeng. 113, (4), 515, 2012.

16 ERLER D.V., EYRE B.D., DAVISON L. The contribution of anammox and denitrification to sediment $\mathrm{N}_{2}$ production in a surface flow constructed wetland. Environ. Sci. Technol. 42, (24), 9144, 2008.

17 ROOKS C., SCHMID M.C., MEHSANA W., TRIMMER $M$. The depth-specific significance and relative abundance of anaerobic ammonium-oxidizing bacteria in estuarine sediments (Medway Estuary, UK). Fems Microbiol. Ecol. 80, (1), 19, 2012.

18 WARD B.B. Significance of anaerobic ammonium oxidation in the ocean. Trends Microbiol. 11, (9), 408, 2003.

19 HAMERSLEY M.R., LAVIK G., WOEBKEN D., RATTRAY J.E., LAM P., HOPMANS E.C., DAMSTE J.S.S., KRUGER S., GRACO M., GUTIERREZ D., KUYPERS M.M.M. Anaerobic ammonium oxidation in the peruvian oxygen minimum zone. Limnol. Oceanogr. 52, (3), 923, 2007.

20 KUYPERS M.M.M., LAVIK G., WOEBKEN D., SCHMID M., FUCHS B.M., AMANN R., JORGENSEN B.B., JETTEN M.S.M. Massive nitrogen loss from the benguela upwelling system through anaerobic ammonium oxidation. P. Natl. Acad. Sci. U.S.A. 102, (18), 6478, 2005.
21 TRIMMER M., NICHOLLS J.C., DEFLANDRE B. Anaerobic ammonium oxidation measured in sediments along the Thames estuary, United Kingdom. Appl. Environ. Microb. 69, (11), 6447, 2003.

22 RISGAARD-PETERSEN N., NIELSEN L.P., RYSGAARD S., DALSGAARD T., MEYER R.L. Application of the isotope pairing technique in sediments where anammox and denitrification coexist. Limnology and Oceanography: Methods 1, 63, 2003.

23 SATO Y., OHTA H., YAMAGISHI T., GUO Y., NISHIZAWA T., RAHMAN M.H., KURODA H., KATO T., SAITO M., YOSHINAGA I., INUBUSHI K., SUWA Y. Detection of anammox activity and 16S rRNA genes in ravine paddy field soil. Microbes and Environments 27, (3), 316, 2012.

24 ZHAO Y.Q., XIA Y.Q., KANA T.M., WU Y.C., LI X.B., YAN X.Y. Seasonal variation and controlling factors of anaerobic ammonium oxidation in freshwater river sediments in the Taihu Lake region of China. Chemosphere 93, (9), 2124, 2013.

25 CROWE S.A., CANFIELD D.E., MUCCI A., SUNDBY B., MARANGER R. Anammox, denitrification and fixed-nitrogen removal in sediments from the Lower St. Lawrence Estuary. Biogeosciences 9, (11), 4309, 2012.

26 LONG A., HEITMAN J., TOBIAS C., PHILIPS R., SONG B. Co-occurring anammox, denitrification, and codenitrification in agricultural soils. Appl. Environ. Microb. 79, (1), 168, 2013. 
